\title{
E2F1 copy number variations in germline and breast cancer: a retrospective study of 222 Italian women
}

\author{
Maria Santa Rocca ${ }^{1}$, Clara Benna ${ }^{2,3}$, Elena Goldin ${ }^{4}$, Andrea Di Nisio ${ }^{1}$, Luca De Toni ${ }^{1}$, Ilaria Cosci ${ }^{5}$, \\ Alberto Marchet ${ }^{6}$, Donato Nitti ${ }^{2,3}$ and Carlo Foresta ${ }^{1 *}$ (D)
}

\begin{abstract}
Background: Breast cancer is the most common neoplasia among women in developed countries. The risk factors of breast cancer can be distinguished in modifiable and unmodifiable factors and, among the latter, genetic factors play a key role. Copy number variations (CNVs) are genetic variants that are classified as rare when present in less than $1 \%$ of the healthy population. Since rare CNVs are often cause of diseases, over the last years, their contribution in carcinogenesis has become a relevant matter of study. E2F1 is a transcriptional factor that plays an important role in regulating cell cycle and apoptosis. Its double and conflicting role is the reason why it acts both as oncogene and as tumour suppressor, depending on cell context. Since anomalies in expression or in number of copies of E2F1 have been related to several cancers, we aimed to study number of germline copies of E2F1 in women with breast cancer in order to better elucidate their contribution as predisposing factor to this tumour.
\end{abstract}

Methods: We performed, hence, a retrospective study on 222 Italian women with breast cancer recruited from October 2002 to December 2007. TaqMan CNV assay and Real-Time PCR were carried out to analyse, respectively, E2F1 CNV and E2F1 expression in the subjects of the study. Chi square test or Fisher's exact test and Student's t-test were used to calculate the frequency of CNVs and differences in continuous variables between groups, respectively.

Results: Intriguingly, we found that 10/222 (4.5\%) women with breast cancer had more copies than controls (0/200, $0 \%)$, furthermore, the number of copies positively correlated with E2F1 gene expression in breast cancer tissue, suggesting that the constitutive gain of the gene could translate into an increased risk of genomic instability. Additionally, we found that altered E2F1 copies were present prevalently in the patients with contralateral breast cancer (20\%) and all of them had a positive family history, both typically associated with hereditary cancer.

Conclusions: Our findings suggest that copy number variations of E2F1 might be a susceptibility factor for breast cancer, however, further studies on large cohorts are to be performed in order to better delineate the phenotype linked to the gain of E2F1 copies.

Keywords: Copy number variations, CNV, E2F1, Breast cancer, Biomarker

*Correspondence: carlo.foresta@unipd.it

1 Department of Medicine, Unit of Andrology and Reproductive Medicine, University Hospital Padua, Via N. Giustiniani 2, 35128 Padua, Italy

Full list of author information is available at the end of the article

\section{Background}

Breast cancer $(\mathrm{BC})$ is the most diagnosed neoplastic disease and represents the second cause of cancerrelated death, after lung cancer, in women (DeSantis et al. 2019). It is a complex and heterogeneous neoplasia whose aetiology involves several risk factors of genetic, original author(s) and the source, provide a link to the Creative Commons licence, and indicate if changes were made. The images or other third party material in this article are included in the article's Creative Commons licence, unless indicated otherwise in a credit line to the material. If material is not included in the article's Creative Commons licence and your intended use is not permitted by statutory regulation or exceeds the permitted use, you will need to obtain permission directly from the copyright holder. To view a copy of this licence, visit http://creativecommons.org/licenses/by/4.0/. 
environmental and behavioural origin (Orlandella et al. 2020). Risk factors of BC are generally distinguished in two groups: extrinsic and intrinsic factors. Extrinsic risk factors include obesity, physical activity, alcohol consumption and ionizing radiation exposure, while intrinsic risk factors are unmodifiable parameters such as race, ethnicity, sex, age, early menarche, late menopause, late age at first birth, nulliparity, hormonal factor, family history and genetic mutations (Kaminska et al. 2015). The latter include rare high-risk mutations (BRCA1 and $B R C A 2$ genes), more moderate susceptibility variants (CHEK2 and ATM genes) and several still unidentified common susceptibility variants associated with low to moderate increased risk. These known risk factors, however, fail to fully elucidate the high incidence of BC.

Based on the status of estrogen receptor (ER), progesterone receptor (PR) and human epidermal growth factor receptor (HER2), different intrinsic subtypes of $B C$ have been classified as: luminal A, luminal B, HER2-enriched and triple negative breast cancer (TNBC).

ER signalling plays a key role in $\mathrm{BC}$ development, in fact, up to $75 \%$ of all breast cancers are ER $\alpha$ positive (Allred et al. 2004; Osborne and Shiff 2011; Dai et al. 2016); therefore, the deregulation of downstream target proteins of ER could partially explain the underlying mechanisms of initiation and development of most of BC.

Transcriptional factor E2F1, member of E2F family including both transcriptional activators and repressors, is a downstream target of ER pathway resulting overexpressed in breast cancer tissue (Li et al. 2018).

E2F1 is a transcriptional activator promoting proliferation, following mitogenic stimulation, or apoptosis, as a response to DNA damage. Therefore, E2F1 can act both as an oncogene and as a tumour suppressor, depending upon the cellular context (Engelmann and Pützer 2012). Abnormalities in $E 2 F 1$ gene expression or $E 2 F 1$ gene amplification have been reported in many types of human cancer (Nelson et al. 2006; Ma et al. 2013; Liang et al. 2016; Kent al. 2017).

Beside gene mutations and hormone receptor (HR) status, copy number variations (CNVs), covering about $12 \%$ of whole human genome (Schaschl et al. 2009), have been largely investigated in $\mathrm{BC}$, because of their role as risk factors for several diseases, including tumours (PetrijBosch et al.1997; Montagna et al. 2003; Casilli et al. 2006; Lesueur et al. 2008; Cybulski et al. 2006; Cybulski et al. 2007; Shlien and Malkin 2009; Kumaran et al. 2017).

In our previous studies, we found that the frequency of germinal CNV of $E 2 F 1$ gene in patients with testicular cancer and melanoma was higher compared to healthy controls and, furthermore, the increased number of copies of $E 2 F 1$ correlated with an increased gene expression, especially under stress conditions, suggesting germline
E2F1 CNVs as risk factor of these two tumours (Rocca et al., 2017; Rocca et al. 2018).

Based on these recent evidence, the aim of this study was to investigate the frequency of CNV of E2F1 in 222 Italian women with breast cancer in order to better elucidate the contribution of this structural variant as a potential predisposing factor to breast carcinogenesis.

\section{Materials and methods}

This study was approved by the Ethics Committee of Padova University Hospital (identifier: prot\#448).

A total of 222 women of Italian origin were retrospectively selected among patients referred to the First Surgical Clinic, University Hospital of Padua-Veneto Institute of Oncology, Italy for breast cancer. We extracted the clinic-pathological data of treated patients between October 2002 and December 2007, using a prospectively maintained database linked to the biobank of the First Surgical Clinic-University Hospital of Padua, Italy. To be included in the study, each case had to meet the following requirements: (1) histologically confirmed diagnosis of breast cancer or metastasis from breast cancer; (2) pathology-based information on TNM stage; (3) follow-up data (minimum follow up: 6 months); (4) availability of DNA for genotyping purposes (Table 1). Tissue specimens were available for 35 out of 222 patients.

200 women, referred to Unit of Andrology and Reproduction Medicine of University Hospital of Padua, with no history of any malignancy were used as controls. All subjects provided written informed consent.

\section{Copy number variation analysis}

Genomic DNA of patients was provided by the abovementioned biobank. DNA was isolated from peripheral blood leucocytes using QIAamp DNA Blood Mini Kit, according to the manufacturer's protocol (Qiagen Inc., Hilden, Germany). Copy number variation was evaluated on 20 ng of genomic DNA. Quantitative real-time polymerase chain reaction (PCR) TaqMan Copy Number Assays were performed using three probes targeting different regions of the E2F1 gene (Hs00576444_cn, Hs01758822_cn and Hs00919582_cn)(Applied Biosystems, Foster City, CA, USA). TaqMan CNV reactions were performed in triplicate using the FAM-dye-labeled assay for E2F1 and VIC-dye labeled RNase P assay. RNase $P$ assay was used to normalize the genomic DNA input.

An internal DNA resulted with two copies of E2F1 both by TaqMan Copy Number Assay and array CGH was used as calibrator. Real-time data were collected by the StepOne Plus 2.1 software, and ABI CopyCaller 2.0 software (Thermo Fisher Scientific Inc, Waltham, MA, USA) was used for data analysis. Copy Number ranging from 1.5 to 2.5 were predicted as $\mathrm{CNV}=2$. Two independent 
Table 1 Description of phenotypic characteristics of patients

\begin{tabular}{|c|c|}
\hline Patient characteristics & $\begin{array}{l}\text { Mean } \pm S D \\
\text { No }\end{array}$ \\
\hline Age at diagnosis (years) & $60 \pm 14.5$ \\
\hline \multicolumn{2}{|l|}{ Menopausal status $(\mathrm{N}=222)$} \\
\hline Premenopausal & 40 \\
\hline Perimenopausal & 27 \\
\hline Menopausal & 155 \\
\hline \multicolumn{2}{|l|}{ Breast cancer $(\mathrm{N}=222)$} \\
\hline \multicolumn{2}{|l|}{ Subtype } \\
\hline $\mathrm{HR}+$ & 195 \\
\hline Triple negative & 6 \\
\hline HER- $2+$ & 21 \\
\hline \multicolumn{2}{|l|}{ Lymph node status $(\mathrm{N}=219)$} \\
\hline Positive & 89 \\
\hline Negative & 130 \\
\hline \multicolumn{2}{|l|}{ Tumour type $(\mathrm{N}=222)$} \\
\hline Invasive ductal carcinoma (IDC) & 161 \\
\hline Ductal carcinoma in situ (DCIS) & 12 \\
\hline Lobular & 35 \\
\hline$D \& L$ & 2 \\
\hline Other & 12 \\
\hline \multicolumn{2}{|l|}{ Histological grade $(\mathrm{N}=199)$} \\
\hline I & 21 \\
\hline$\|$ & 105 \\
\hline III & 73 \\
\hline \multicolumn{2}{|l|}{ Location $(\mathrm{N}=211)$} \\
\hline Unilateral & 204 \\
\hline Bilateral & 7 \\
\hline \multicolumn{2}{|l|}{ Familial history $(\mathrm{N}=31)$} \\
\hline Yes & 14 \\
\hline No & 17 \\
\hline \multicolumn{2}{|l|}{ Tumour size $(\mathrm{N}=181)$} \\
\hline$<2 \mathrm{~cm}$ & 107 \\
\hline$>2 \mathrm{~cm}$ & 74 \\
\hline \multicolumn{2}{|l|}{ Vascular invasion $(\mathrm{N}=195)$} \\
\hline Yes & 35 \\
\hline No & 160 \\
\hline
\end{tabular}

assays were performed for each sample to confirm results.

\section{RNA isolation, CDNA synthesis and real-time PCR}

Total RNA was extracted from 35 breast cancer tissues of patients included in the study using the RNeasy Mini Kit (Qiagen, Hilden, Germany). cDNA was synthesized from $250 \mathrm{ng}$ of total RNA using SuperScript III (Invitrogen, Carlsbad, CA, USA) and random hexamers. Real Time PCR were performed in a $20 \mu \mathrm{l}$ final volume containing 20 ng of cDNA, 1X Power SYBR Green PCR Master Mix
(Applied Biosystem, Foster City, CA, USA), and a mix of forward and reverse primers $(1 \mathrm{mmol} / \mathrm{l}$ each). The following primers were used: E2F1: forward 5'-CATCAG TACCTGGCCGAGAG- $3^{\prime}$ and reverse $5^{\prime}$-CCCGGG GATTTCACACCTTT-3'. Human GAPDH was used as a housekeeping gene: forward 5'-TCGACAGTCAGC CGCATCTT- $3^{\prime}$ and reverse $5^{\prime}$-AGGCGCCCAATACGA CCAAA- ${ }^{\prime}$. Real Time PCR was performed on thermocycler StepOne plus (Applied Biosystems, Foster City, CA, USA) and relative quantification was performed using Delta Delta $C t(\Delta \Delta C t)$ method.

\section{Statistical analysis}

Statistical analysis of the data was conducted with SPSS 21.0 for Windows (SPSS, Chicago, IL). Statistical power was calculated comparing two proportions: the frequency of $E 2 F 1$ altered copies in healthy controls and the frequency of $E 2 F 1$ altered copies in patients with $\mathrm{BC}$. The $\alpha$ level of significance was set at 0.05 .

Differences in the frequency of CNVs between groups were compared using the Chi square test, or Fisher's exact test when expected frequency was $<5$. Differences in continuous variables between groups were analysed by Student's t-test. P value $\leq 0.05$ was considered statistically significant.

\section{Results}

On Table 1 are reported main characteristics of patients. Age did not differ between cases and controls (Age $=60 \pm 14.5$ and $59 \pm 10.4$, respectively). Pre-, peri- and post-menopausal women were also comparable between cases and controls (data not shown). In the group of cancer patients, we found a significantly higher portion of women $(4.5 \%, 10 / 222)$ with more than two copies of $E 2 F 1$, compared with controls where none of subjects harboured $E 2 F 1 \mathrm{CNVs}>2(0 \%, 0 / 200 ; p=0.002)$. The statistical power of this study was $80 \%$.

At this point, we compared patient's phenotypic characteristics between subjects with $\mathrm{CNV}>2$ and those with $\mathrm{CNV}=2$. Table 2 summarises this analysis. In particular, patients with more than 2 copies of $E 2 F 1$ had less lymph nodes-positive $(p=0.04)$ and prevalently a bilateral tumour $(p=0.04)$, and, additionally, they had positive BC family history $(p=0.001)$. No difference has emerged for other traits.

Gene expression analysis on breast cancer tissue of 35 out 222 patients $(\mathrm{N}=4$ with $\mathrm{CNV}>2$ and $\mathrm{N}=31$ with $\mathrm{CNV}=2$ in blood) (Table 3 ) has revealed a positive and statistically significant correlation between $E 2 F 1$ expression and number of copies $(p=0.004)$ (Fig. 1a). Specifically, three out four individuals with germline $\mathrm{CNV}>2$ showed more copies also in breast tissue. 
Table 2 Pathological characteristics in two group of patients. Data are presented as proportion of individuals within each category

\begin{tabular}{|c|c|c|c|}
\hline & $C N V=2$ & $C N V>2$ & $P$ value \\
\hline Age at diagnosis (years) & $60.4 \pm 14.5$ & $61.4 \pm 13.6$ & 0.74 \\
\hline Menopausal status & & & 0.70 \\
\hline Premenopausal & $20.9 \%$ & $10 \%$ & \\
\hline Perimenopausal & $3.7 \%$ & $0.0 \%$ & \\
\hline Menopausal & $75.4 \%$ & $90 \%$ & \\
\hline Estrogen receptor & & & 0.84 \\
\hline Positive & $67.8 \%$ & $80 \%$ & \\
\hline Negative & $32.2 \%$ & $20 \%$ & \\
\hline Progesterone receptor & & & 0.35 \\
\hline Positive & $53 \%$ & $30 \%$ & \\
\hline Negative & $47 \%$ & $70 \%$ & \\
\hline HER-2 status & & & 0.99 \\
\hline Positive & $70.1 \%$ & $70 \%$ & \\
\hline Negative & $29.9 \%$ & $30 \%$ & \\
\hline Palpable tumour & & & 0.07 \\
\hline Yes & $93.6 \%$ & $70 \%$ & \\
\hline No & $6.4 \%$ & $30 \%$ & \\
\hline Lymph node status & & & $0.04^{*}$ \\
\hline Negative & $58.2 \%$ & $80 \%$ & \\
\hline Positive & $41.8 \%$ & $20 \%$ & \\
\hline Tumour type & & & 0.93 \\
\hline Invasive ductal carcinoma (IDC) & $72.9 \%$ & $80 \%$ & \\
\hline Ductal carcinoma in situ (DCIS) & $5.7 \%$ & $0.0 \%$ & \\
\hline Lobular & $15.7 \%$ & $20 \%$ & \\
\hline$D \& L$ & $1 \%$ & $0.0 \%$ & \\
\hline Other & $2.9 \%$ & $0.0 \%$ & \\
\hline Histological grade & & & 0.36 \\
\hline I & $11.1 \%$ & $0 \%$ & \\
\hline$\|$ & $51.9 \%$ & $70 \%$ & \\
\hline III & $37 \%$ & $30 \%$ & \\
\hline Location & & & $0.04^{*}$ \\
\hline Unilateral & $95.5 \%$ & $80 \%$ & \\
\hline Bilateral & $2.5 \%$ & $20 \%$ & \\
\hline Familial history & & & $0.001^{*}$ \\
\hline Yes & $45 \%$ & $100 \%$ & \\
\hline No & $55 \%$ & $0 \%$ & \\
\hline Size (cm) & & & 0.64 \\
\hline$<2$ & $59 \%$ & $60 \%$ & \\
\hline$>2$ & $41 \%$ & $40 \%$ & \\
\hline Vascular invasion & & & 0.21 \\
\hline Yes & $81 \%$ & $0 \%$ & \\
\hline No & $19 \%$ & $100 \%$ & \\
\hline
\end{tabular}

* $p$ value $<0.05$
Table 3 Description of phenotypic characteristics of 35 out of 222 patients on which E2F1 expression and copy number assay were performed

\begin{tabular}{|c|c|c|c|}
\hline & $C N V=2,(N=31)$ & $C N V>2,(N=4)$ & $P$ value \\
\hline Age at diagnosis (years) & $60.48 \pm 16.76$ & $57.5 \pm 10.88$ & 0.808 \\
\hline Menopausal status & & & 0.458 \\
\hline Premenopausal & $25.8 \%$ & $0 \%$ & \\
\hline Perimenopausal & $3.2 \%$ & $0 \%$ & \\
\hline Menopausal & $71.0 \%$ & $100 \%$ & \\
\hline Estrogen receptor & & & 0.523 \\
\hline Positive & $83.9 \%$ & $100 \%$ & \\
\hline Negative & $16.1 \%$ & $0 \%$ & \\
\hline Progesterone receptor & & & 0.454 \\
\hline Positive & $86.2 \%$ & $100 \%$ & \\
\hline Negative & $19.4 \%$ & $0 \%$ & \\
\hline HER-2 status & & & 0.082 \\
\hline Positive & $74.2 \%$ & $25 \%$ & \\
\hline Negative & $25.8 \%$ & $75 \%$ & \\
\hline Palpable tumour & & & 0.601 \\
\hline Yes & $87.1 \%$ & $100 \%$ & \\
\hline No & $12.9 \%$ & $0 \%$ & \\
\hline Lymph node status & & & 0.082 \\
\hline Negative & $25.8 \%$ & $75 \%$ & \\
\hline Positive & $74.2 \%$ & $25 \%$ & \\
\hline Tumour type & & & 0.791 \\
\hline $\begin{array}{l}\text { Invasive ductal carci- } \\
\text { noma (IDC) }\end{array}$ & $80.6 \%$ & $75 \%$ & \\
\hline $\begin{array}{l}\text { Ductal carcinoma in situ } \\
\text { (DCIS) }\end{array}$ & $0 \%$ & $0 \%$ & \\
\hline Lobular & $19.4 \%$ & $25 \%$ & \\
\hline$D \& L$ & $0 \%$ & $0 \%$ & \\
\hline Other & $0 \%$ & $0 \%$ & \\
\hline Histological grade & & & 0.304 \\
\hline 1 & $9.7 \%$ & $0 \%$ & \\
\hline$\|$ & $35.5 \%$ & $75 \%$ & \\
\hline III & $54.8 \%$ & $25 \%$ & \\
\hline Location & & & 0.114 \\
\hline Unilateral & $100 \%$ & $75 \%$ & \\
\hline Bilateral & $0 \%$ & $25 \%$ & \\
\hline Familial history & & & $<0.001$ \\
\hline Yes & $6.5 \%$ & $100 \%$ & \\
\hline No & $93.5 \%$ & $0 \%$ & \\
\hline Size & & & 0.530 \\
\hline$<2 \mathrm{~cm}$ & $38.7 \%$ & $50 \%$ & \\
\hline$>2 \mathrm{~cm}$ & $61.3 \%$ & $50 \%$ & \\
\hline Vascular invasion & & & 0.553 \\
\hline Yes & $29 \%$ & $0 \%$ & \\
\hline No & $71 \%$ & $100 \%$ & \\
\hline
\end{tabular}

Furthermore, expression levels were significantly different between subjects with $\mathrm{CNV}=2$ and subjects with CNV $>2(p<0.001)$ (Fig. 1b). 


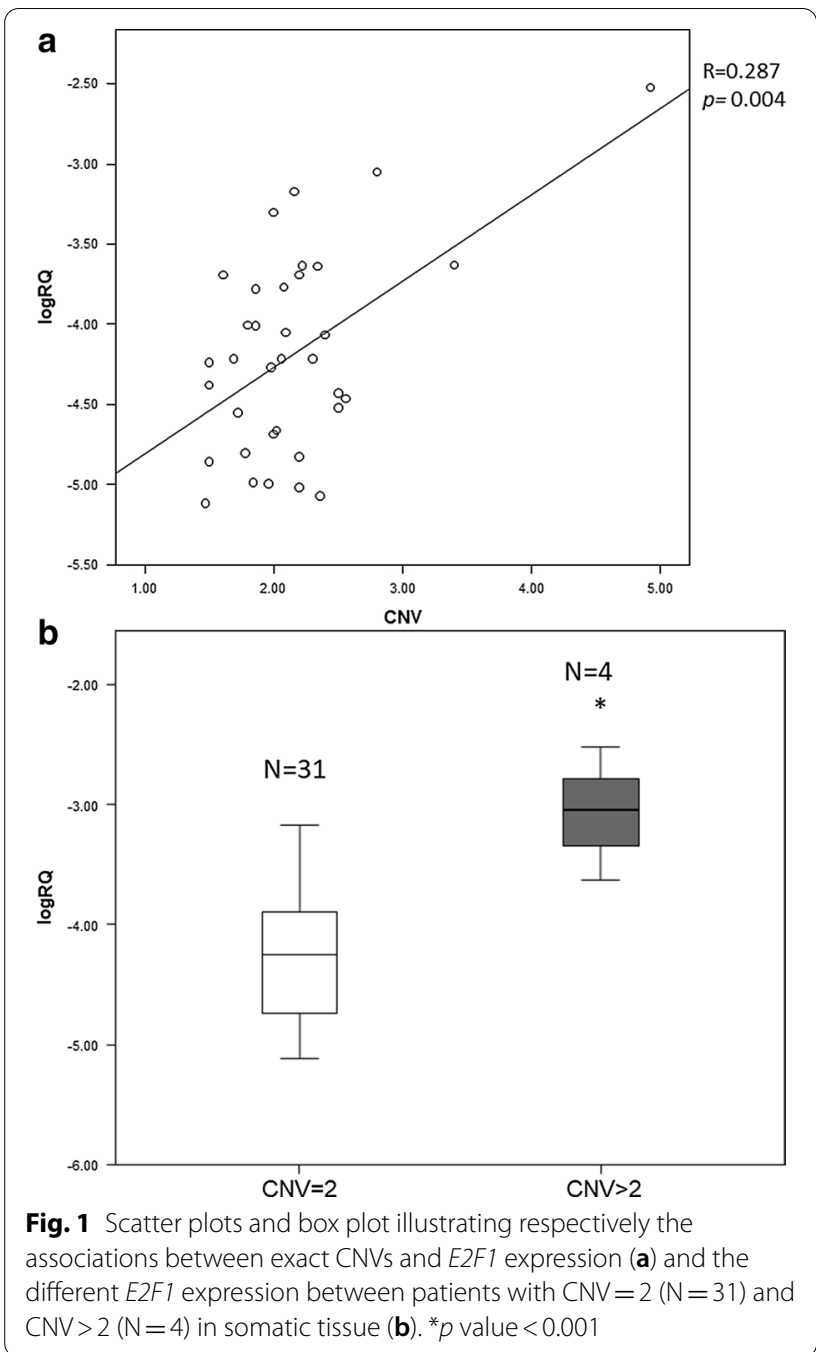

\section{Discussion}

$\mathrm{BC}$ is the most common malignant tumour among women in the majority of the developed countries and it is normally distinguished into four main molecular subtypes. Although established risk factors are associated with each subtypes (Yang et al. 2007; Sisti et al. 2016; Holm et al. 2017), however, the constant research of novel biomarkers is of fundamental importance in clinical practice so that the patients may have an early diagnosis and specific treatment.

Approximately $5-10 \%$ of breast cancers are hereditary and up to $25 \%$ are due to mutations in the following high-penetrance genes: BRCA1, BRCA2, PTEN, TP53, CDH1, and STK11 (Oosterwijk et al. 2014; Shiovitz and Korde 2015). Therefore, molecular screening programmes are of huge relevance in terms of prevention, especially in women with $\mathrm{BC}$ family history. Indeed, individuals having first degree relatives with genetic mutations, mainly in $B R C A 1$ and $B R C A 2$ genes, have an increased risk of developing BC (Ripperger et al. 2009).

Over last years, several groups have studied germinal $\mathrm{CNVs}$ as predisposing factors to cancer. CNVs are structural variations ranging from $1 \mathrm{~kb}$ to several $\mathrm{Mb}$ in length, referred to as polymorphisms if present in more than $1 \%$ of population. However, rare CNVs have been described in some tumours, including breast cancer (Kumaran et al. 2017), suggesting a role of these variants as susceptibility factors (Lee and Scherer 2010).

Recently, germinal CNVs of E2F1 have been proposed as genetic risk factor for testicular cancer and melanoma (Rocca et al. 2017; Rocca et al. 2019). In both studies, patients showed a higher frequency of altered E2F1 copies compared to controls.

E2F1 is a member of E2F family and acts as a transcriptional factor of genes encoding proteins implicated in cell-cycle progression and apoptosis (Attwool et al. 2004). E2F1 expression has been found to be increased in breast cancer tissue, pointing out the important contribution of this transcriptional factor in breast carcinogenesis $(\mathrm{Li}$ et al. 2018).

Based on large body evidence regarding the role of $\mathrm{CNV}$ in disease susceptibility and the altered expression of $E 2 F 1$ in breast cancer, we have analysed CNVs of $E 2 F 1$ in a cohort of 222 women with breast cancer.

Interestingly, we found that the frequency of CNVs of $E 2 F 1$ was higher in the patients compared to controls (4.5\%), suggesting therefore that altered CNVs of E2F1 may play a key role as predisposing factor of $\mathrm{BC}$ as well as it was reported in patients with testicular cancer and melanoma (Rocca et al. 2017; Rocca et al. 2019). This finding, intriguingly, is corroborated by gene expression analysis that has pointed out a higher expression of $E 2 F 1$ in breast tissue from three out of four patients with more germline copies of the gene, included in somatic tissue analysis. Therefore, it is likely that inherited germinal $\mathrm{CNVs}$, in combination with other extrinsic or intrinsic factors, may contribute to increase genomic instability in breast tissue, resulting in the deregulation of E2F1 target proteins.

Patients with more copies of E2F1 were almost similar to patients with normal copies, except for three clinical characteristics. Indeed, we found a statistically significant difference among two groups for following parameters: lymph nodes status, laterality and family history.

Contralateral breast cancer $(\mathrm{CBC})$ is less common than unilateral breast cancer (UBC) and it has been supposed to have mainly a genetic cause (Mack et al. 2002). Indeed, women carrying mutations in BRCA1, $B R C A 2$ and $C H E C K$ genes have a higher risk of developing $\mathrm{CBC}$ and the estimation of the risk is higher in carriers of germinal mutations, confirming the strong 
genetic contribution (Robson et al. 2017; Kramer et al. 2020). Based on these evidence, the finding of altered E2F1 CNVs in patients with CBC suggests that this structural variant, likely inherited, as well as it occurs in inherited germline mutations of BRCA genes, may contribute to an increased risk of $\mathrm{CBC}$. This hypothesis, hence, could explain the early age at diagnosis and $\mathrm{BC}$ family history of one of the patients with more copies of E2F1 and CBC.

It is well known, indeed, that hereditary cancers are generally characterized from an earlier age of onset of BC (Brandt et al. 2008); therefore, the combination of early age of onset and positive $\mathrm{BC}$ family history represents a very strong risk factor and is generally associated with germline mutation in BRCA1 gene (Anders et al. 2009).

Interestingly, the patient harbouring more copies of $E 2 F 1$ with $\mathrm{CBC}$ and positive family history was also carrier of a mutation in BRCA1 gene. This finding could suggest that carriers of inherited rare germline mutations and CNVs of E2F1 may have an increased risk of $\mathrm{BC}$ compared to the individuals having only one of these two genetic variants. It is known that BRCA1 plays a crucial role in the preserving genome integrity, hence, the loss of function of BRCA1 could promote cell cycle progression also of those cells with more copies of $E 2 F 1$, translating into the deregulation of E2F1 target genes due its overexpression.

In this study, additionally, we have found a significant difference between the two groups of the patients in relation to the presence of lymph nodes positive. Although we have not enough data to clarify this result, we could suppose that this parameter may contribute to better delineate the phenotype linked to the patients having more copies of E2F1.

In conclusion, although this study adds information to the research of new biomarkers of $\mathrm{BC}$, the small size of samples and the missing data about the inheritance pattern of the identified CNVs is a limitation, therefore, these results should be confirmed from study on a large cohort of women selected for BC family history.

However, based on our results, we suppose that the high frequency of $E 2 F 1 \mathrm{CNV}$ might predispose to $\mathrm{BC}$, therefore, molecular screening of this gene, mainly in women with positive family history, would be of fundamental importance to estimate the risk of recurrence into the family. Furthermore, the confirmation of germinal CNVs of $E 2 F 1$ as novel predictive biomarkers of $\mathrm{BC}$ could have impressive implications in clinical practice regarding the choice of targeted therapies against this malignant cancer.

\section{Conclusions}

In conclusion, although this study adds information to the research of new biomarkers of $\mathrm{BC}$, the small size of samples and the missing data about the inheritance pattern of the identified CNVs is a limitation, therefore, these results should be confirmed from study on a large cohort of women selected for BC family history.

However, based on our results, we suppose that the high frequency of E2F1 CNV might predispose to BC, therefore, molecular screening of this gene, mainly in women with positive family history, would be of fundamental importance to estimate the risk of recurrence into the family. Furthermore, the confirmation of germinal CNVs of $E 2 F 1$ as novel predictive biomarkers of $\mathrm{BC}$ could have impressive implications in clinical practice regarding the choice of targeted therapies against this malignant cancer.

\section{Abbreviations}

CNVs: Copy number variations; BC: Breast cancer; ER: Estrogen receptor; PR: Progesterone receptor; HER2: Human epidermal growth factor; TNBC: Triple negative breast cancer; CBC: Contralateral breast cancer; UBC: Unilateral breast cancer.

\section{Acknowledgements}

We acknowledge the personnel of the Biobank of the 1st Surgical Clinic, University Hospital of Padova - Istituto Oncologico Veneto (IOV-IRCCS) Padova, Italy.

\section{Authors' contributions}

MSR and CF gave their contribution to the overall conception and design of the study and were responsible for drafting the article. CB and EG contributed to clinical database and text revision. DN and AM was responsible for recruitment of patients. ADN contributed to statistical analysis and interpretation data. LDT and IC contributed to interpretation data. All authors participated in the work for appropriate portions of the content. All authors read and approved the final manuscript.

\section{Funding}

No funding.

Availability of data and materials

All data generated or analysed during this study are included in this published article.

\section{Declarations}

\section{Ethics approval and consent to participate}

This study was approved by the Ethics Committee of Padova University Hospital (identifier: prot\#448). Written informed consent was obtained from all patients.

\section{Consent for publication}

A written informed consent to publication has been obtained from the patients.

\section{Competing interests}

The authors declare that they have no conflict of interests.

\section{Author details}

${ }^{1}$ Department of Medicine, Unit of Andrology and Reproductive Medicine, University Hospital Padua, Via N. Giustiniani 2, 35128 Padua, Italy. ${ }^{2}$ Department of Surgery Oncology and Gastroenterology, University of Padua, Padua, Italy. ${ }^{3}$ First Surgical Clinic, University Hospital Padua, Padua, Italy. ${ }^{4}$ Breast Unit, 
Azienda ULSS n.8 Berica, Vicenza, Italy. ${ }^{5}$ Veneto Institute of Oncology IOVIRCCS, Padua, Italy. ${ }^{6}$ Multidisciplinary Day-Surgery Unit, University Hospital Padua, Padua, Italy.

Received: 28 December 2020 Accepted: 4 March 2021 Published online: 10 March 2021

\section{References}

Allred DC, Brown P, Medina D. The origins of estrogen receptor alpha-positive and estrogen receptor alpha-negative human breast cancer. Breast Cancer Res. 2004;6(6):240-5. https://doi.org/10.1186/bcr938.

Anders CK, Johnson R, Litton J, Phillips M, Bleyer A. Breast cancer before age 40 years. Semin Oncol. 2009;36(3):237-49. https://doi.org/10.1053/j.semin oncol.2009.03.001.

Attwooll C, Lazzerini Denchi E, Helin K. The E2F family: specific functions and overlapping interests. EMBO J. 2004;23(24):4709-16. https://doi. org/10.1038/sj.emboj.7600481.

Brandt A, Lorenzo Bermejo J, Sundquist J, Hemminki K. Age of onset in familial cancer. Ann Oncol. 2008;19(12):2084-8. https://doi.org/10.1093/annonc/ man527.

Casilli F, Tournier I, Sinilnikova OM, Coulet F, Soubrier F, Houdayer C, et al. The contribution of germline rearrangements to the spectrum of BRCA2 mutations. J Med Genet. 2006;43:e49. https://doi.org/10.1002/ humu.22938.

Cybulski C, Wokolorczyk D, Huzarski T, Byrski T, Gronwald J, Gorski B, et al. A large germline deletion in the Chek2 kinase gene is associated with an increased risk of prostate cancer. J Med Genet. 2006;43:863-6. https://doi. org/10.1136/jmg.2006.044974.

Cybulski C, Wokolorczyk D, Huzarski T, Byrski T, Gronwald J, Gorski B, et al. A deletion in CHEK2 of 5,395 bp predisposes to breast cancer in Poland. Breast Cancer Res Treat. 2007;102:119-22. https://doi.org/10.1007/s1054 9-006-9320-y.

Dai X, Xiang L, Li T, Bai Z. Cancer hallmarks, biomarkers and breast cancer molecular subtypes. J Cancer. 2016;7(10):1281-94. https://doi. org/10.7150/jca.13141.

DeSantis CE, Ma J, Gaudet MM, Newman LA, Miller KD, Goding Sauer A, et al. Breast cancer statistics, 2019. CA Cancer J Clin. 2019;69(6):438-51. https:// doi.org/10.3322/caac.21583.

Engelmann D, Pützer BM. The dark side of E2F1: in transit beyond apoptosis. Cancer Res. 2012;72(3):571-5. https://doi.org/10.1158/0008-5472. CAN-11-2575.

Holm J, Eriksson L, Ploner A, Eriksson M, Rantalainen M, Li J, et al. Assessment of breast cancer risk factors reveals subtype heterogeneity. Cancer Res. 2017:77:3708-17. https://doi.org/10.1158/0008-5472.CAN-16-2574.

Kamińska M, Ciszewski T, Łopacka-Szatan K, Miotła P, Starosławska E. Breast cancer risk factors. Prz Menopauzalny. 2015;14(3):196-202. https://doi. org/10.5114/pm.2015.54346.

Kent L, Bae S, Tsai SY, Tang X, Srivastava A, Koivisto C, et al. Dosage-dependent copy number gains in E2f1 and E2f3 drive hepatocellular carcinoma. J Clin Invest. 2017;127(3):830-42. https://doi.org/10.1172/JCl87583.

Kramer I, Hooning MJ, Mavaddat N, Hauptmann M, Keeman R, Steyerberg EW, et al. Breast cancer polygenic risk score and contralateral breast cancer risk. Am J Hum Genet. 2020;107(5):837-48. https://doi.org/10.1016/j. ajhg.2020.09.001.

Kumaran M, Cass CE, Graham K, Mackey JR, Hubaux R, Lam W, et al. Germline copy number variations are associated with breast cancer risk and prognosis. Sci Rep. 2017;7(1):14621.

Lee C, Scherer SW. The clinical context of copy number variation in the human genome. Expert Rev Mol Med. 2010;12:e8. https://doi.org/10.1017/S1462 399410001390

Lesueur F, de Lichy M, Barrois M, Durand G, Bombled J, Avril MF, et al. The contribution of large genomic deletions at the CDKN2A locus to the burden of familial melanoma. Br J Cancer. 2008;99:364-70. https://doi. org/10.1038/sj.bjc.6604470.

Li Y, Huang J, Yang D, Xiang S, Sun J, Li H, et al. Expression patterns of E2F transcription factors and their potential prognostic roles in breast cancer. Oncol Lett. 2018;15(6):9216-30. https://doi.org/10.3892/ol.2018.8514.
Liang YX, Lu JM, Mo RJ, He HC, Xie J, Jiang FN, et al. E2F1 promotes tumor cell invasion and migration through regulating CD147 in prostate cancer. Int J Oncol. 2016;48(4):1650-8. https://doi.org/10.3892/ijo.2016.3364.

Ma X, Gao Y, Fan Y, Ni D, Zhang Y, Chen W, et al. Overexpression of E2F1 promotes tumor malignancy and correlates with TNM stages in clear cell renal cell carcinoma. PLoS ONE. 2013;8(9):e73436. https://doi. org/10.1371/journal.pone.0073436.

Mack TM, Hamilton AS, Press MF, Diep A, Rappaport EB. Heritable breast cancer in twins. Br J Cancer. 2002;87:294-300. https://doi.org/10.1038/ sj.bjc.6600429.

Montagna M, Dalla Palma M, Menin C, Agata S, De Nicolo A, Chieco-Bianchi L, et al. Genomic rearrangements account for more than one-third of the BRCA1 mutations in northern Italian breast/ovarian cancer families. Hum Mol Genet. 2003;12:1055-61. https://doi.org/10.1093/hmg/ddg120.

Nelson MA, Reynolds SH, Rao UNM, Goulet AC, Feng Y, Beas A, et al. Increased gene copy number of the transcription factor E2F1 in malignant melanoma. Cancer Biol Ther. 2006;5(4):407-12. https://doi.org/10.4161/ cbt.5.4.2512.

Oosterwijk JC, de Vries J, Mourits MJ, de Bock GH. Genetic testing and familial implications in breast-ovarian cancer families. Maturitas. 2014;78(4):2527. https://doi.org/10.1016/j.maturitas.2014.05.002.

Orlandella FM, DeStefano AE, lervolino PLC, Buono P, Soricelli A, Salvatore G. Dissecting the molecular pathways involved in the effects of physical activity on breast cancers cells: a narrative review. Life Sciences. 2020;118:790. https://doi.org/10.1016/j.lfs.2020.118790.

Osborne CK, Schiff R. Mechanisms of endocrine resistance in breast cancer. Annu Rev Med. 2011;62:233-47. https://doi.org/10.1146/annurevmed-070909-182917.

Petrij-Bosch A, Peelen T, van Vliet M, van Eijk R, Olmer R, Drusedau M, et al. BRCA1 genomic deletions are major founder mutations in Dutch breast cancer patients. Nat Genet. 1997;17:341-5. https://doi.org/10.1038/ng119 7-341.

Ripperger T, Gadzicki D, Meindl A, Schlegelberger B. Breast cancer susceptibility: current knowledge and implications for genetic counselling. Eur J Hum Genet. 2009;17(6):722-31. https://doi.org/10.1038/ejhg.2008.212.

Robson ME, Reiner AS, Brooks JD, Concannon PJ, John EM, Mellemkjaer L, et al. Association of common genetic variants with contralateral breast cancer risk in the WECARE Study. J Natl Cancer Inst. 2017;109(10):51. https://doi. org/10.1093/jnci/djx051.

Rocca MS, Di Nisio A, Marchiori A, Ghezzi M, Opocher G, Foresta C, et al. Copy number variations of E2F1: a new genetic risk factor for testicular cancer. Endocr Relat Cancer. 2017;24(3):119-25. https://doi.org/10.1038/s4159 8-017-14799-7.

Rocca MS, Benna C, Mocellin S, Rossi CR, Msaki A, Di Nisio A, et al. E2F1 germline copy number variations and melanoma susceptibility. J Transl Med. 2019;17(1):181. https://doi.org/10.1186/s12967-019-1933-0.

Schaschl H, Aitman TJ, Vyse TJ. Copy number variation in the human genome and its implication in autoimmunity. Clin Exp Immunol. 2009;156(1):12-6. https://doi.org/10.1111/j.1365-2249.2008.03865.X.

Shiovitz S, Korde LA. Genetics of breast cancer: a topic in evolution. Ann Oncol. 2015;26(7):1291-9. https://doi.org/10.1093/annonc/mdv022.

Shlien A, Malkin D. Copy number variations and cancer. Genome Med. 2009;1 (6):62. https://doi.org/10.1186/gm62.

Sisti JS, Collins LC, Beck AH, Tamimi RM, Rosner BA, Eliassen AH. Reproductive risk factors in relation to molecular subtypes of breast cancer: results from the nurses' health studies. Int J Cancer. 2016;138:2346-56. https://doi. org/10.1002/ijc.29968.

Yang XR, Sherman ME, Rimm DL, Lissowska J, Brinton LA, Peplonska B, et al. Differences in risk factors for breast cancer molecular subtypes in a population-based study. Cancer Epidemiol Biomarkers Prev. 2007;16:43943. https://doi.org/10.1158/1055-9965.EPI-06-0806.

\section{Publisher's Note}

Springer Nature remains neutral with regard to jurisdictional claims in published maps and institutional affiliations. 